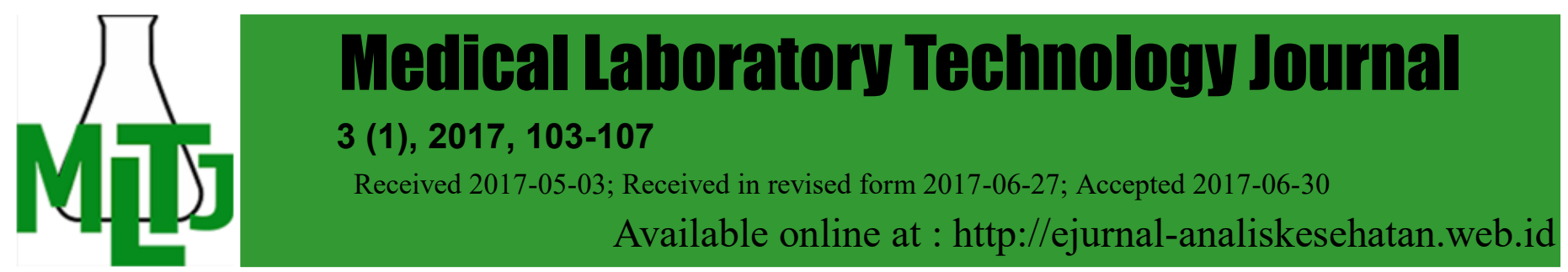

\title{
PENGARUH VARIASI SUHU AWAL REAGEN TERHADAP KADAR GLUKOSA DARAH METODE ENZIMATIK
}

\author{
Yayuk Kustiningsih, Nastiti Megawati, Jasmadi Joko Kartiko, Leka Lutpiatina \\ Jurusan Analis Kesehatan Poltekkes Kemenkes Banjarmasin \\ JI Mistar Cokrokusumo 4a Banjarbaru \\ e-mail: yayukkustiningsih71@gmail.com
}

\begin{abstract}
Pre-analysis phase is the first step that determines the quality of the examination results, in this case, is the preparation of glucose work reagent. Glucose is one of the clinical examination clinical parameters that are often done in the laboratory. This glucose examination uses enzymatic methods. Enzyme activity is influenced by several factors, namely temperature, $\mathrm{pH}$, substrate level, enzyme level, and inhibitor. Glucose examination performed at a temperature of $20-25^{\circ} \mathrm{C}$ or $37^{\circ} \mathrm{C}$, but there are still laboratories in the field that is less attention to the initial temperature conditions of this reagent. This study aims to determine the effect of initial temperature variations of reagents on blood glucose levels of enzymatic methods. The research used Quasi Experimental research method with Posttest-Only Control Group Design design. The sample of this research used serum of a respondent who had no history of Diabetes Mellitus disease with 4 replication at each treatment. The results of the study with the initial temperature of $10^{\circ} \mathrm{C}, 13^{\circ} \mathrm{C}, 16^{\circ} \mathrm{C}, 19^{\circ} \mathrm{C}, 22^{\circ} \mathrm{C}$ and $25^{\circ} \mathrm{C}$ (control) respectively of $62.71 \mathrm{mg} / \mathrm{dL}$; $65,74 \mathrm{mg} / \mathrm{dL} ; 72.45 \mathrm{mg} / \mathrm{dL} ; 76.91 \mathrm{mg} / \mathrm{dL} ; 89.12 \mathrm{mg} / \mathrm{dL}$ and $97.19 \mathrm{mg} / \mathrm{dL}$, the results of this study showed an increase in glucose levels in each treatment. Based on the results of linear regression analysis obtained a significance value of 0.000 with $\alpha=0.05$, which means Ho is rejected, so it can be concluded that there is an influence of initial temperature variation of reagent on blood glucose level. For the next researcher can do research about the effect of the initial temperature of reagent 22-38 oC on blood glucose enzymatic method. And the influence of incubation time on blood glucose level of enzymatic method.
\end{abstract}

Keywords: initial temperature of reagent; enzymatic methods; glucose

Abstrak: Tahap pra analisa merupakan tahap awal yang sangat menentukan kualitas hasil pemeriksaan, dalam hal ini adalah persiapan reagen kerja glukosa. Glukosa merupakan salah satu parameter pemeriksaan kimia klinik yang sering dilakukan di laboratorium. Pemeriksaan glukosa ini menggunakan metode enzimatik. Aktivitas enzim dipengaruhi oleh beberapa faktor, yaitu suhu, $\mathrm{pH}$, kadar substrat, kadar enzim, dan inhibitor. Pemeriksaan glukosa dilakukan pada suhu $20-25^{\circ} \mathrm{C}$ atau $37^{\circ} \mathrm{C}$, namun dilapangan masih ada laboratorium yang kurang memperhatikan kondisi suhu awal reagen ini. Penelitian ini bertujuan untuk mengetahui pengaruh variasi suhu awal reagen terhadap kadar glukosa darah metode enzimatik. Penelitian menggunakan metode penelitian Quasi Eksperiment dengan rancangan Posttest Only Control Group Design. Sampel penelitian menggunakan serum seorang responden yang tidak memiliki riwayat penyakit Diabetes Mellitus dengan 4 kali replikasi pada setiap perlakuan. Hasil penelitian dengan suhu awal $10^{\circ} \mathrm{C}, 13^{\circ} \mathrm{C}, 16^{\circ} \mathrm{C}, 19^{\circ} \mathrm{C}, 22^{\circ} \mathrm{C}$ dan $25^{\circ} \mathrm{C}$ (kontrol) masing-masing sebesar $62,71 \mathrm{mg} / \mathrm{dL} ; 65,74 \mathrm{mg} / \mathrm{dL} ; 72,45 \mathrm{mg} / \mathrm{dL} ; 76,91 \mathrm{mg} / \mathrm{dL} ; 89,12 \mathrm{mg} / \mathrm{dL}$ dan 97,19 mg/dL, hasil penelitian ini menunjukkan peningkatan kadar glukosa pada tiap perlakuan. Berdasarkan hasil analisa uji Regresi linier didapatkan nilai signifikansi sebesar 0,000 dengan $\alpha=0,05$, yang berarti Ho ditolak, sehingga dapat disimpulkan bahwa ada pengaruh variasi suhu awal reagen terhadap kadar glukosa darah. Bagi peneliti selanjutnya dapat melakukan penelitian mengenai pengaruh suhu awal reagen 22-38 ${ }^{\circ} \mathrm{C}$ terhadap kadar glukosa darah metode enzimatik.dan pengaruh waktu inkubasi terhadap kadar glukosa darah metode enzimatik.

Kata kunci: suhu awal reagen; metode enzimatik; glukosa 


\section{PENDAHULUAN}

Menurut Hendrik L. Bloom dalam Notoatmodjo (2007) menjelaskan bahwa derajat kesehatan masyarakat dipengaruhi oleh empat faktor utama yaitu faktor lingkungan, perilaku, pelayanan kesehatan dan keturunan.

Faktor ketiga yang mempengaruhi derajat kesehatan masyarakat yaitu pelayanan kesehatan. Laboratorium sebagai salah satu sarana pelayanan kesehatan dituntut untuk memberikan pelayanan seoptimal mungkin, sebab semakin hari konsumen akan semakin kritis dengan teknik pelayanan maupun hasil pemeriksaan yang dikeluarkan oleh suatu laboratorium klinik. Oleh karena itu dituntut kepada pengelola laboratorium untuk selalu melakukan kontrol atas segala kegiatan yang dilaksanakan baik tahap pra analisa, analisa, dan post analisa (Puslabkes, 1999). Persiapan reagen kerja merupakan bagian dari tahap pra analisa. Tahap ini sangat menentukan kualitas hasil pemeriksaan sampel yang nantinya akan dihasilkan dan mempengaruhi proses berikutnya.

Berdasarkan observasi dari parameter kimia darah yang diperiksa di laboratorium klinik RSUD Ratu Zalecha Martapura untuk tahun 2015 berjumlah 22.467 pemeriksaan glukosa, 6.285 pemeriksaan kolesterol total, 5.909 pemeriksaan asam urat, 6.094 pemeriksaan trigliserida, 11.772 pemeriksaan SGOT, 11.876 pemeriksaan SGPT data pemeriksaan memberikan informasi bahwa pemeriksaan glukosa darah paling sering diperiksa dibandingkan pemeriksaan lain.

Metode uji glukosa darah yang digunakan pada laboratorium klinik RSUD Ratu Zalecha Martapura adalah berdasarkan pemeriksaan enzimatik. Metode enzimatik yang digunakan untuk uji glukosa darah ada tiga macam, yaitu: glukosa heksokinase, oksidase dan dehydrogenase (Astuti G., 2012) Laboratorium ini menggunakan metode oksidase. Penelitian yang pernah dilakukan menunjukkkan hasil tidak ada perbedaan yang bermakna terkait kadar glukosa darah dalam menggunakan metode glukosa oksidase, glukosa dehidrogenase dan glukosa heksokinase (Baharuddin, Nurulita A, Afif M, 2015).

Pada pemeriksaan glukosa darah metode enzimatik tersebut terdapat reagen warna yang berupa enzim, sehingga persiapan pra analisa reagen ini harus diperhatikan karena akan mempengaruhi kepekaan reaksi kimia yang terjadi.

Aktivitas enzim dipengaruhi oleh be- berapa faktor, yaitu suhu, $\mathrm{pH}$, kadar substrat, kadar enzim, dan inhibitor (Panil, 2008). Kecepatan reaksi meningkat seiring peningkatan suhu, tetapi dengan berjalannya reaksi enzimatik, titik maksimal akan dicapai dan laju reaksi akan menurun dengan peningkatan suhu (Saryono, 2011). Pada suhu rendah reaksi kimia berlangsung lambat, sedangkan pada suhu yang lebih tinggi reaksi berlangsung lebih cepat sampai pada suhu optimal $\left(37^{\circ} \mathrm{C}\right)$ (Poedjiadi, 2006).

Penelitian tentang enzim oleh Kusumadjaja dan Rita (2005), didapatkan hasil bahwa aktivitas papain mengalami kenaikan seiring dengan peningkatan suhu dari $32^{\circ} \mathrm{C}$ hingga $50^{\circ} \mathrm{C}$. Aktivitas maksimum dicapai pada suhu $50^{\circ} \mathrm{C}$, yang berarti bahwa laju reaksi enzimatik sangat dipengaruhi oleh suhu.

Laboratorium klinik yang kurang memperhatikan kondisi suhu dari reagen kerja masih ditemukan. Kondisi dari reagen kerja yang masih dingin telah digunakan untuk pemeriksaan, seharusnya reagen dikondisikan pada suhu kamar terlebih dahulu sebelum digunakan untuk pemeriksaan karena berdasarkan kit reagen pemeriksaan dilakukan pada suhu $20-25^{\circ} \mathrm{C}$ atau $37^{\circ} \mathrm{C}$. Ketidaktepatan penggunaan reagen ini dapat berpengaruh terhadap hasil pemeriksaan laboratorium. Berdasarkan uji pendahuluan terhadap reagen glukosa setelah pengeluaran dari kulkas sampai kondisi suhu kamar diperoleh hasil pada 0 menit $=12^{\circ} \mathrm{C}, 10$ menit $=$ $16^{\circ} \mathrm{C}, 20$ menit $=20^{\circ} \mathrm{C}, 30$ menit $=22^{\circ} \mathrm{C}$, dan 40 menit $=24^{\circ} \mathrm{C}$. Pada uji pendahuluan kedua diperoleh hasil pada 0 menit $=9^{\circ} \mathrm{C}, 10$ menit $=13^{\circ} \mathrm{C}, 20$ menit $=17^{\circ} \mathrm{C}, 30$ menit $=19^{\circ} \mathrm{C}$, dan 40 menit $=21^{\circ} \mathrm{C}$. Data hasil uji pendahuluan tersebut menunjukkan bahwa untuk mendapatkan suhu kamar $\left(20-25^{\circ} \mathrm{C}\right)$ diperlukan pendiaman $\pm 20-40$ menit setelah dikeluarkan dari kulkas. Tujuan penelitian ini adalah untuk mengetahui pengaruh variasi suhu awal reagen terhadap kadar glukosa darah metode enzimatik.

\section{BAHAN DAN METODE}

Jenis penelitian yang digunakan adalah Quasi Eksperimen. Rancangan penelitian yang digunakan yaitu Posttest Only Control Group Design yaitu mengukur pengaruh perlakuan (intervensi) pada kelompok eksperimen kengan cara membandingkan kelompok tersebut dengan kelompok kontrol (Notoatmodjo, 2010). 
Objek penelitian ini adalah reagen glukosa di Laboratorium Klinik Analis Kesehatan Politeknik Kesehatan Kemenkes Banjarmasin.

Variasi suhu awal reagen pada penelitian ini dikelompokkan menjadi 6 perlakuan yaitu $10^{\circ} \mathrm{C}, 13^{\circ} \mathrm{C}, 16^{\circ} \mathrm{C}, 19^{\circ} \mathrm{C}, 22^{\circ} \mathrm{C}$ dan $25^{\circ} \mathrm{C}$ (sebagai kontrol). Variabel bebas dalam penelitian ini adalah variasi suhu awal reagen. Variabel terikat dalam penelitian ini adalah kadar glukosa darah.

Pembuatan serum dengan cara darah yang telah diambil dimasukkan kedalam tabung sentrifuge kemudian didiamkan selama 30-45 menit. Darah tersebut disentrifuge selama 10 menit dengan kecepatan 3000 rpm. Serum yang diperoleh dipisahkan (Susilo, 2014).

Persiapan Reagen glukosa dengan cara sebelum melakukan pemeriksaan, reagen glukosa yang digunakan masing-masing diberikan perlakuan kelompok reagen I dikondisikan pada suhu awal $10^{\circ} \mathrm{C}$. Kelompok reagen II dikondisikan pada suhu awal $13^{\circ} \mathrm{C}$. Kelompok reagen III dikondisikan pada suhu awal $16^{\circ} \mathrm{C}$.Kelompok reagen IV dikondisikan pada suhu awal $19^{\circ} \mathrm{C}$. Kelompok reagen $\mathrm{V}$ dikondisikan pada suhu awal $22^{\circ} \mathrm{C}$. Kelompok reagen $\mathrm{VI}$ dikondisikan pada suhu awal $25^{\circ} \mathrm{C}$ (sebagai kontrol)

Cara pengondisian suhu awal reagen pada tiap perlakuan tersebut dilakukan dengan memasukkan masing-masing $1000 \mu \mathrm{l}$ reagen glukosa kedalam 7 buah tabung reaksi. Dimana 1 buah digunakan untuk blanko, 1 buah digunakan untuk standar, 4 buah digunakan untuk sampel (4 kali pengulangan), dan 1 buah digunakan untuk kontrol suhu. Dimana setelah reagen dikeluarkan dari kulkas, suhu reagen diukur dengan termometer, ditunggu sampai suhu yang dikehendaki tercapai (suhu untuk tiap perlakuan tercapai), kemudian dilakukan pemeriksaan glukosa darah.

Prosedur Pemeriksaan glukosa darah metode GOD-PAP tes enzimatik kolorimetrik secara semi-mikro merek Human memasukkan dalam tabung reaksi seperti tabel 1.

Tabel 1. Prosedur Pemeriksaan glukosa darah metode GOD-PAP

\begin{tabular}{lccc}
\hline & Blanko & Standar & Sampel \\
\hline Reagen Glukosa & $1000 \mu \mathrm{l}$ & $1000 \mu \mathrm{l}$ & $1000 \mu \mathrm{l}$ \\
Standar & - & $10 \mu \mathrm{l}$ & - \\
Serum & - & - & $10 \mu \mathrm{l}$ \\
\hline
\end{tabular}

Mencampur dan mendiamkan selama 10 menit pada suhu kamar $\left(25^{\circ} \mathrm{C}\right)$.Mengukur konsentrasi standar dan sampel terhadap blanko dengan fotometer dengan panjang gelombang $546 \mathrm{~nm}$ tidak lebih dari 60 menit.

Perhitungan Konsentrasi Glukosa

$\underset{[\mathrm{mg} / \mathrm{dL}]}{\text { Konsentrasi glukosa }}=\frac{\Delta \text { A sampel }}{\Delta \mathrm{A} \text { standar }} \times$ Konsentrasi Standar

\section{HASIL DAN PEMBAHASAN}

Berdasarkan penelitian yang dilakukan di Laboratorium Kimia Klinik Jurusan Analis Kesehatan pada bulan Mei 2016 didapatkan hasil pemeriksaan kadar glukosa darah metode enzimatik (GOD-PAP) pada penggunaan reagen dengan suhu awal $10^{\circ} \mathrm{C}$, $13^{\circ} \mathrm{C}, 16^{\circ} \mathrm{C}, 19^{\circ} \mathrm{C}, 22^{\circ} \mathrm{C}$ dan $25^{\circ} \mathrm{C}$ disajikan pada Tabel 2.

Tabel 2. Kadar glukosa darah dengan penggunaan reagen pada berbagai variasi suhu awal reagen

\begin{tabular}{|c|c|c|c|c|c|c|c|}
\hline \multirow[t]{2}{*}{$\begin{array}{l}\text { Suhu } \\
\text { Awal } \\
\text { Reagen }\end{array}$} & \multirow[t]{2}{*}{ Blanko } & \multirow[t]{2}{*}{ Standar } & \multicolumn{4}{|c|}{$\begin{array}{c}\text { Kadar Glukosa } \\
\text { Darah (mg/dL) } \\
\text { Pengulangan } \\
\text { ke- }\end{array}$} & \multirow[t]{2}{*}{ Ratarata } \\
\hline & & & 1 & 2 & 3 & 4 & \\
\hline $10^{\circ} \mathrm{C}$ & 0,000 & 89,76 & 66,1 & 67,18 & 63,18 & 54,38 & 62,71 \\
\hline $13^{\circ} \mathrm{C}$ & 0,000 & 93,24 & 67,24 & 61,33 & 66,25 & 68,14 & 65,74 \\
\hline $16^{\circ} \mathrm{C}$ & 0,000 & 94,06 & 69,02 & 72,84 & 73,56 & 74,38 & 72,45 \\
\hline $19^{\circ} \mathrm{C}$ & 0,000 & 99,33 & 75,75 & 79,23 & 76,64 & 76,05 & 76,91 \\
\hline $22^{\circ} \mathrm{C}$ & 0,000 & 99,77 & 87,58 & 87,16 & 89,12 & 92,63 & 89,12 \\
\hline $25^{\circ} \mathrm{C}$ & 0,000 & 100,02 & 97,18 & 96,09 & 100,83 & 94,66 & 97,19 \\
\hline
\end{tabular}

Hubungan antara variasi suhu awal reagen terhadap kadar glukosa darah dapat dilihat pada Gambar 1.

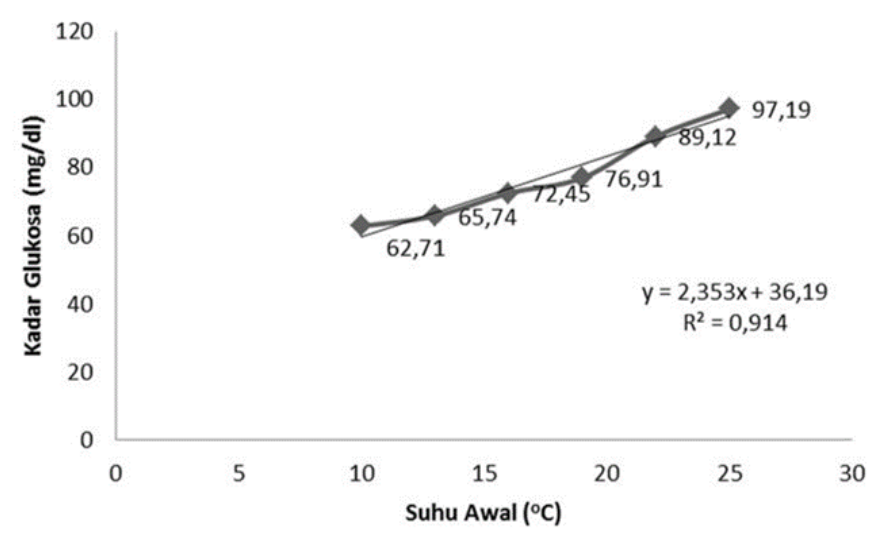

Gambar 1 Grafik hubungan antara variasi suhu awal reagen terhadap kadar glukosa darah 
Untuk mendapatkan nilai persentase perbedaan kadar glukosa darah metode enzimatik pada penggunaan reagen dengan suhu awal $10^{\circ} \mathrm{C}, 13^{\circ} \mathrm{C}, 16^{\circ} \mathrm{C}, 19^{\circ} \mathrm{C}, 22^{\circ} \mathrm{C}$ dan $25^{\circ} \mathrm{C}$. Maka dapat dilakukan perhitungan dengan rumus \% Perbedaan Kadar Glukosa =

$$
\frac{\text { selisih kadar glukosa }}{\text { kadar glukosa (kontrol) }} \times 100 \% \text {. }
$$

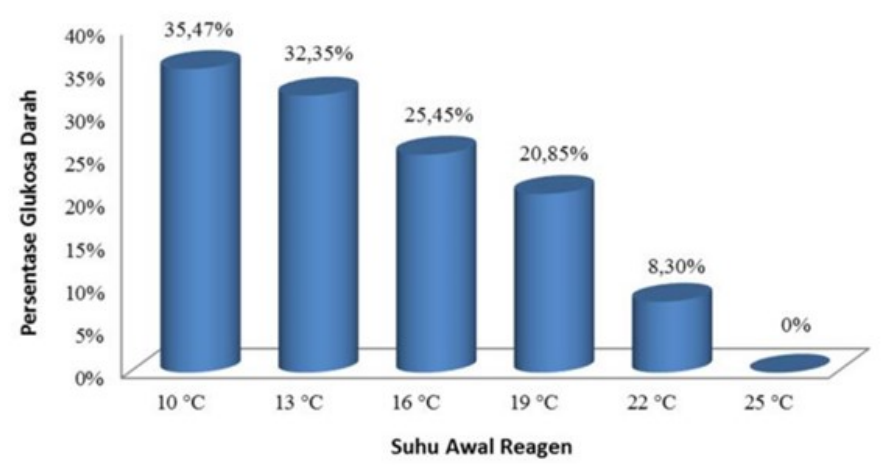

Gambar 2 Grafik persentase perbedaan kadar glukosa darah metode enzimatik pada penggunaan reagen dengan suhu awal $10^{\circ} \mathrm{C}$, $13^{\circ} \mathrm{C}, 16^{\circ} \mathrm{C}, 19^{\circ} \mathrm{C}, 22^{\circ} \mathrm{C}$ dan $25^{\circ} \mathrm{C}$

Berdasarkan hasil uji analisa statistik menggunakan uji regresi Linier didapatkan nilai signifikansi $=0,000$. Sesuai ketentuan apabila nilai signifikansi $<\alpha=0,05$ maka dapat dinyatakan bahwa ada pengaruh bermakna penggunaan suhu awal reagen terhadap kadar glukosa darah. Dengan persamaan garis Linier $y=2,353 x+36,186$ dari persamaan $y=b x+a$, dimana y adalah variabel terikat (kadar glukosa darah), $x$ adalah variabel bebas (suhu awal reagen), a adalah konstanta dan b adalah koefisien regresi. Persamaan ini dapat digunakan untuk memperkirakan kadar glukosa darah seseorang pada penggunaan suhu awal reagen yang telah diketahui dan sebaliknya.

Selanjutnya nilai $R$ Square yang didapat sebesar 0,914. Hasil ini menunjukkan bahwa persentase pengaruh suhu awal reagen terhadap kadar glukosa darah adalah sebesar $91,4 \%$.

Penelitian ini menggunakan 1 sampel dengan 6 (enam) perlakuan dan tiap perlakuan dilakukan pengulangan sebanyak 4 kali. 6 (enam) perlakuan tersebut adalah pengukuran kadar glukosa darah dengan menggunakan suhu awal reagen $10^{\circ} \mathrm{C}, 13^{\circ} \mathrm{C}$, $16^{\circ} \mathrm{C}, 19^{\circ} \mathrm{C}, 22^{\circ} \mathrm{C}$ dan $25^{\circ} \mathrm{C}$. Pada kit reagen pemeriksaan dilakukan pada suhu $20-25^{\circ} \mathrm{C}$ atau $37^{\circ} \mathrm{C}$, sehingga perlakuan pada suhu awal $25^{\circ} \mathrm{C}$ digunakan sebagai kontrol dalam penelitian ini.
Menurut Panil (2008), aktivitas enzim dipengaruhi oleh beberapa faktor, yaitu suhu, $\mathrm{pH}$, kadar substrat, kadar enzim, dan inhibitor.

Dari hasil penelitian didapatkan kadar glukosa pada suhu awal $10^{\circ} \mathrm{C}=62,71 \mathrm{mg} / \mathrm{dl}$; $13^{\circ} \mathrm{C}=65,74 \mathrm{mg} / \mathrm{dl} ; 16^{\circ} \mathrm{C}=72,45 \mathrm{mg} / \mathrm{dl} ; 19^{\circ} \mathrm{C}$ $=76,91 \mathrm{mg} / \mathrm{dl} ; 22^{\circ} \mathrm{C}=89,12 \mathrm{mg} / \mathrm{dl}$ dan $25^{\circ} \mathrm{C}=$ $97,19 \mathrm{mg} / \mathrm{dl}$. Dilihat dari data pengukuran glukosa tersebut terjadi peningkatan kadar glukosa darah pada tiap perlakuannya yang dimulai dari penggunaan suhu awal reagen $10^{\circ} \mathrm{C}$ sampai dengan $25^{\circ} \mathrm{C}$. Peningkatan kadar glukosa ini disebabkan oleh salah satu faktor yang mempengaruhi aktivitas enzim yaitu suhu. Pada suhu yang rendah reaksi kimia berlangsung lambat, sedangkan pada suhu yang lebih tinggi reaksi berlangsung lebih cepat sampai pada suhu optimal (Poedjiadi, 2006). Peninggian suhu reaksi sampai pada suhu optimal akan meningkatkan jumlah molekul yang dapat bereaksi, sehingga jumlah partikel yang bertumbukan lebih banyak dibandingkan pada suhu rendah. Hal ini disebabkan karena pada suhu tinggi energi kinetik partikel akan lebih besar, sehingga jumlah tumbukan semakin banyak dan laju reaksi akan meningkat (Murray, 2003).

Hal ini sesuai dengan penelitian Kusumadjaja dan Rita (2005) yang menyatakan bahwa aktivitas papain mengalami peningkatan dari suhu $32^{\circ} \mathrm{C}$ sampai dengan 50 ${ }^{\circ} \mathrm{C}$.

Enzim glukosa oksidase dalam keadaan kering dan murni berwarna kuning pucat, pada suhu 0 oC stabil selama 2 tahun. Pada penyimpanan suhu $250 C$ enzim glukosa oksidase hanya stabil selama 8 bulan. Aktivitas enzim glukosa oksidase hilang bila dipanaskan pada suhu diatas suhu $370 \mathrm{C}$. $\mathrm{pH}$ optimum enzim glukosa oksidase adalah 5,6. Larutan enzim glukosa oksidase stabil pada kisaran $\mathrm{pH} 3$ - 8, di luar kisaran $\mathrm{pH}$ tersebut enzim mengalami kerusakan lebih cepat (Steven and Price, 1993).

Hasil penelitian diatas menunjukkan bahwa untuk melakukan pemeriksaan parameter laboratorium kimia klinik harus sesuai atau memperhatikan Standard Operational Procedur (SOP) yang ada. 


\section{KESIMPULAN}

Kadar glukosa darah pada penggunaan reagen suhu awal $10^{\circ} \mathrm{C}=62,71 \mathrm{mg} / \mathrm{dl} ; 13^{\circ} \mathrm{C}=$ $65,74 \mathrm{mg} / \mathrm{dl} ; 16^{\circ} \mathrm{C}=72,45 \mathrm{mg} / \mathrm{dl} ; 19^{\circ} \mathrm{C}=$ $76,91 \mathrm{mg} / \mathrm{dl} ; 22^{\circ} \mathrm{C}=89,12 \mathrm{mg} / \mathrm{dl}$ dan $25^{\circ} \mathrm{C}=$ $97,19 \mathrm{mg} / \mathrm{dl}$. Persentase perbedaan kadar glukosa darah dengan penggunaan suhu awal $10^{\circ} \mathrm{C}=35,47 \% ; 13^{\circ} \mathrm{C}=32,35 \% ; 16^{\circ} \mathrm{C}=$ $25,45 \% ; 19^{\circ} \mathrm{C}=20,86 \% ; 22^{\circ} \mathrm{C}=8,30 \%$ dan $25^{\circ} \mathrm{C}=0 \%$ (kontrol). Berdasarkan hasil uji statistik dengan Regresi Linier terdapat pengaruh bermakna penggunaan suhu awal reagen terhadap kadar glukosa darah, dengan nilai signifikansi 0,000 .

\section{SARAN}

Melakukan penelitian pengaruh variasi suhu awal reagen terhadap kadar glukosa darah dengan suhu awal $22^{\circ} \mathrm{C}$ sampai dengan $38^{\circ} \mathrm{C}$. Melakukan penelitian pengaruh lamanya waktu inkubasi terhadap kadar glukosa darah.

\section{DAFTAR PUSTAKA}

Astuti, G. (2012). Analitik Pemeriksaan Glukosa dengan Glukosameter. Dalam: Pemeriksaan Laboratorium pada Diabetes Melitus. Departemen Patologi Klinik, Fak. Kedokteran UI.

Baharuddin, Nurulita, A., \& Arif, M. (2015). Uji Glukosa Darah Antara Metode Heksokinase Dengan Glukosa Oksidase Dan Glukosa Dehidrogenase Di Diabetes Melitus. Indonesian Journal Of Clinical Pathology And Medical Laboratory, 21 (2).

Kusumadjaja, A., \& Rita, P. (2005). Penentuan Kondisi Optimum Enzim Papain dari Pepaya Burung Varietas Jawa (Carica papaya). Indo.J.Chem, 5(2), 147-151.

Murray, R., Daryl, K., Peter, A., \& Victor, W. (2003). Biokimia Harper. Jakarta: EGC.

Notoatmodjo, S. (2007). Promosi Kesehatan dan IImu Perilaku. Jakarta: PT Rineka Cipta.

Panil, Z. (2008). Memahami teori dan praktik Biokimia Dasar Medis untuk Mahasiswa Kedokteran, Keperawatan, Gizi dan Analis Kesehatan. Jakarta: EGC.

Poedjiadi, A., \& Supriyanti, F. (2006). Dasardasar Biokimia. Jakarta: Universitas Indonesia.

Puslabkes. (1999). Pedoman Praktek Laboratorium Yang Benar. Jakarta: Depkes RI.

Saryono. (2011). Biokimia Enzim. Yogyakarta: Nuha Medika.

Steven, L., \& Price, W. . (1992). Fundamental of enzymology, Second Edition. New
York: Oxford University.

Susilo, R. (2014). Flebotomi Teori dan Praktek untuk Laboratorium Kesehatan. Bali: 89 Printing. 